\title{
The Potential of Augmented Reality for Vocational High School Learning Amid Covid-19 Spread
}

\author{
Ismi Solikhatun ${ }^{1 *}$, Sukirno ${ }^{2}$, Arif Wahyu Widodo ${ }^{3}$, and Sayidatul Maslahah ${ }^{4}$ \\ ${ }^{1234}$ Graduate School, Yogyakarta State University, Yogyakarta, 55281 \\ *corresponding author. Email: Ismisolikhatun.2019@student.uny.ac.id
}

\begin{abstract}
Due to Covid-19 spread, the learning system in Indonesia changes from classroom learning to distance learning which has impact on practical learning. Practical training in vocational high school is primary important to prepare students in industrial environment. A technology is needed to combine reality and virtual into 3-dimensional form and projected in real time as known as augmented reality. Augmented reality can extend the integration of digital learning and real world. The purpose of this research to determine the possible augmented reality for vocational high school learning amid pandemic. This research used a systematic literature consisting of planning, selection, extraction and execution. This research used related previous research through the potential of augmented reality in the learning process sourced from article conference and journal since 2013-2020. The result shows that augmented reality is used as an alternative media in education learning process at all level. Augmented reality has various potentials issues used as an interactive media to manipulate the practical learning object, increase motivation, increase learning outcomes and reduce cost for long term.
\end{abstract}

Keywords: augmented reality, potential, Covid-19, vocational high school

\section{INTRODUCTION}

Since declaring Covid-19 emergency in March 2020, Indonesian government has begun to take various actions through distance learning policy to anticipate Covid-19 transmission. Barriers in conducting distance learning in Indonesia are the changes in learning dynamics, including classroom learning is transferred into distance learning, transformed learning media is based on technology, learning methods used are still in the adjustment stage, adjusting process of graduation standards and grade promotion and the parents' role in controlling the children learning process at home [1], students have low learning independence [2] and resulted in students' low motivation and learning outcomes [3]. Students consider that distance learning is not interesting as classroom learning [4].

Distance learning occurs from elementary to higher education, including vocational high school. Vocational high school prepares the students and graduates to face the industrial world and have competence in vocational field [5], [6]. Vocational high school graduates have to master high competency skills evidenced by a competency certificate as a condition for entering global competition to make them able to work according to their fields [7]. Students from vocational high school are required to master skills in accordance with their fields to carry out learning practices to suit industry needs. Inadequate facilities and infrastructure are serious problem for vocational high school [8], especially during Covid-19 spread, when students just meet through distance learning without carrying out practical learning in school. In addition to implementing practice, a step used to align skills in school with the needs of industrial world is done through work practices [9]. However, due to this pandemic, work practices at industrial world are stopped while learning are conducted through online system.

Technology in the form of mobile-based learning media is a way to deal with distance learning barrier [10]. The use of technology in distance learning can be conducted by using mobile-based learning media through e-books, games and simulations [8]. Mobilebased learning through simulation aims to provide a more concrete learning experience through imitation design that are closer to a real condition [8]. Augmented Reality (AR) is a technology that can be used to implement the simulation learning as a learning media that can facilitate students' understanding during learning because it can visualize material and contain cognitive content; it can be used as learning media for teachers as well [11]. The development of AR technology in learning is supported by Internet users in Indonesia increase amounted 17\%, where $64 \%$ of population uses the Internet access in 2020 and $94 \%$ among Internet users use smartphone as the operating device [12]. The aim of this research is to determine the potential of AR in vocational learning amid pandemic. This research synthesizes a literature review 
of AR potential in learning activities, especially distance learning for vocational high school students.

\section{LITERATURE OF RELATED REVIEW 2.1. Distance Learning}

Distance learning is a learning process conducted between teachers and students without contacting face to face and carrying out in different places [13]. Provisions for distance learning are regulated in the Circular Letter of the Minister of Education and Culture Number 4 Year 2020. The differences between distance learning and classroom learning are the interaction occurred between teachers and students, the role of human resources, the technology used, program types, implementation management and etc (Ahmad, 2020).

\subsection{Augmented Reality}

AR combines two situation between real and virtual world [14] and changes the way humans interact with the physical environment. The technology of AR drives the users to interact between the physical objects and the virtual objects by using the mobile phone camera or tablet [15]. The rapid development of mobile phone media has made AR technology widely adopted by humans to improve the way humans see and feel in various ways in everyday life [16]. AR technology has been widely adopted in various fields including tourism, marketing and learning environment [16]. One of the most common use of AR is Instagram application in the form of Instagram filter. Augmented Reality has some features such as immersion, navigation and interaction [17]. The first feature is immersion consisting of aspects of the physical environment and the condition in which the users enter AR activities [18]. Interaction in AR results in changes in the physical appearance of technology and will change users' immersion [19]. The second feature is navigation where digital information is developed in the real environment as users' perspective [19]. Navigation changes the users' perspective on how objects are placed. Navigation aims to direct users' interaction with the technology used [20]. The third feature is interaction in real time, where the interaction can increase users' understanding, memory and imagination of objects [19]. These three features are expected able to increase users' satisfaction, help to understand comprehension and be useful for learning tasks requiring experiment.

\section{METHOD}

This was a systematic review research. The systematic review used a stage model developed by Chitu Okoli [21] consisting of planning, selection, extraction and execution. This article used keywords $A R$ in vocational high school, implementation AR through mobile phones and literature review of the benefits of AR for education in its search. In this research, there were 88 articles identified and produced 25 relevant articles from journals and conferences articles during 2013-2020.

\section{RESULT AND DISCUSSION \\ 4.1. Augmented Reality on Education}

AR has been widely adopted in education and used as an interactive learning media. The use of AR in learning is based on Theory of Interactive Media Effect. Theory of Interactive Media Effects (TIME) states that media is related to human psychology, the media used, how to communicate to others, where the media will provide immersive experiences for users and influence the affective, cognitive and behavioral aspects [22]. Immersive experience will be received when the users interact with the application and give their consent to the activity (dragging, clicking, scrolling, etc) [23]. TIME proposed by Sundar [22] explains that the success rate of media use depends on the type of media used in an interaction. In interactive learning media, the communicant is no longer as a message passive recipient but actively involved in learning media through various interaction activities and message construction [22]. Interactive learning media for learning process is AR [24] - [27].

\subsection{The possible Augmented Reality in vocational education}

Pandemic gives various challenges in the educational world, especially for vocational students. Amid the limitations, the vocational students who graduate during distance learning still have competency demands in accordance with the needs of industrial world. Distance learning with AR simulation for the implementation of practical learning can be used as an alternative solution. AR learning combines the virtual and real world at the same time and is very useful for designing simulated learning [28]. Simulation learning using AR functions as a substitute for laboratory practices and industrial word practices [29] which is crucial during this pandemic, especially for vocational students. AR is able to describe 3D models, manipulate virtual objects and provide experiences based on abstract concepts [30]. Compared to practical learning videos, learning using AR is interactive, so there is two-way learning between students and learning media [25], [30]. Students can carry out AR learning independently and flexibly [31]. Previous research has succeeded in developing and making learning media with augmented effectively and validly for use in vocational high school learning [27], [32] - [38] 


\subsubsection{Improving students' understanding}

AR is able to improve students' understanding of the material [39], [40]. Therefore, the utilize of AR in the learning process can lead the improvement of students' learning outcomes [28], [40]. AR provides understanding to students to improve higher thinking skill, creativity and critical analysis [25], [41].

\subsubsection{Having a longer memory level}

The use of AR is able to improve users' memory with interesting experiences gained during media used [42].

\subsubsection{Increasing students' motivation}

AR technology in the learning environment has a positive impact on students' motivation [19], [30], [39], [43]. AR is an interactive learning media that can increase students' interest, concentration and satisfaction with the use of new technology in learning [42]. The use of AR provides exciting new experiences for students.

\subsubsection{No need requiring any advanced devices to operate}

Most of AR technologies can be run by mobile phone [44] and students can download the available applications for free. Mobile phone is a technology tending to be cheap and is mostly owned by society. Mobile phone is a flexible device which can be used anywhere, easy to carry and anytime.

\subsubsection{Reducing costs}

The use of AR in learning reduces direct and material costs as well as laboratory maintenance costs [42]. Although the cost of developing AR tends to be expensive, its long-term utilization is cheaper than traditional learning [42]. Costs in AR application can also be reduced by changing book markers into cards, thereby reducing printing costs and making them more flexible to be carried anywhere [45].

\section{CONCLUSION}

AR is an alternative technology that can be used to simulate practical learning for vocational high school students by visualizing objects in 3D and still involving two-way interaction between students and learning media. Students are able to visualize practical learning in the classroom through an interactive AR technology by using mobile phone during distance learning amid the pandemic. Besides, potential in AR-based learning at vocational high school is able to improve students' understanding, have longer memory, increase motivation, do not require sophisticated equipment to operate and reduce learning costs.

\section{REFERENCES}

[1] A. R. Mansyur, "Dampak Covid-19 terhadap dinamika pembelajaran di Indonesia," Education and Learning Journal, vol. 1, no. 2, p. 113, 2020 , doi: 10.33096/eljour.v1i2.55.

[2] M. Churiyah et al., "Indonesia education readiness conducting distance learning in Covid-19 pandemic situation," International Journal of Multicultural and Multireligious Understanding, vol. 7, no. 6, p 491, 2020, doi: 10.18415/ijmmu.v7i6.1833.

[3] A. Rahardjo, "Learning motivation and students ' achievement in learning english: a case study at secondary school students in the covid-19 pandemic situation," JELITA: Journal of English Language Teaching and Literature, vol. 1, no. 2, pp. 56-64, 2020.

[4] B. Mulyanti, W. Purnama, and R. E. Pawinanto, "Distance learning in vocational high schools during the Covid-19 pandemic in West Java province, Indonesia," Indonesian Journal of Science and Technology, vol. 5, no. 2, pp. 271-282, 2020, doi: 10.17509/ijost.v5i2.24640.

[5] S. Suranto, M. Muhyadi, and D. Mardapi, "Pengembangan instrumen evaluasi uji kompetensi keahlian (UKK) administrasi perkantoran di SMK,' Jurnal Penelitian dan Evaluasi Pendidikan, vol. 18 , no. 1, pp. 98-114, 2014, doi: 10.21831/pep.v18i1.2127.

[6] N. Santiyadnya, "Implementasi uji kompetensi dan pengaruhnya terhadap kualitas lulusan SMK negeri bidang teknologi di Provinsi Bali," Jurnal Pendidikan Teknologi dan Kejuruan, vol. 8, no. 1, pp. 1-16, 2011, [Online]. Available: http://repositorio.unan.edu.ni/2986/1/5624.pdf.

[7] S. Suhartadi, "Pengembangan model perangkat uji kompetensi di sekolah menengah kejuruan teknologi dalam bidang permesinan," Teknologi dan Kejuruan, vol. 34, no. 2, pp. 155-166, 2011.

[8] P. B. Herlandy et al., "A virtual laboratory application for vocational productive learning using augmented reality," Jurnal Pendidikan Teknologi dan Kejuruan, vol. 25, no. 2, pp. 194-203, 2019, doi: 10.21831/jptk.v25i2.26504.

[9] M. F. Rochman, Z. X. Ming, and A. Masduki, "A study of major problem in Indonesian animation vocational high school," PEOPLE: International Journal of Social Sciences, vol. 6, no. 1, pp. 512520, 2020, doi: 10.20319/pijss.2020.61.512520.

[10] R. Pakpahan and Y. Fitriani, "Analisa pemanfaatan teknologi informasi dalam pembelajaran jarak jauh di tengah pandemi virus corona Covid-19," JISAMAR (Journal of Information System, Applied, Management, Accounting and Researh), vol. 4, no. 2, pp. 30-36, 2020. 
[11] M. E. Ismail et al., "The effect of an augmented reality teaching kit on visualization, cognitive load and teaching styles," Jurnal Pendidikan Teknologi dan Kejuruan, vol. 24, no. 2, pp. 178-184, 2018, doi: 10.21831 /jptk.v24i2.20031.

[12] A. T. Haryanto, "Riset: ada 175,2 juta pengguna internet di Indonesia." Detiknet. https://inet.detik.com/cyberlife/d-4907674/risetada-1752-juta-pengguna-internet-di-indonesia (accessed Nov. 14, 2020).

[13] I. F. Ahmad, "Alternative assessment in distance learning in emergencies spread of coronavirus disease (Covid-19)," Jurnal Pedagogik, vol. 07, no. 01, pp. 195-222, 2020.

[14] M. Akçayır and G. Akçayır, "Advantages and challenges associated with augmented reality for education: A systematic review of the literature," Educational Research Review, vol. 20, pp. 1-11, 2017, doi: 10.1016/j.edurev.2016.11.002.

[15] K. T. Huang et al., "Augmented versus virtual reality in education: An exploratory study examining science knowledge retention when using augmented reality/virtual reality mobile applications," Cyberpsychology, Behavior, and Social Networking, vol. 22, no. 2, pp. 105-110, 2019, doi: 10.1089/cyber.2018.0150.

[16] R. Li et al., "Interacting with augmented reality: How does location-based AR enhance learning?," IFIP Conference on Human-Computer Interaction, pp. 616-623, 2013, doi: 10.1007/978-3-642-404801 1_43.

[17] B. Kye and Y. Kim, "'Investigation on the relationships among media characteristics, presence, flow, and learning effects in augmented reality based learning," Journal of Educational Technology, vol. 24, no. 4, pp. 193-223, 2008, doi: 10.17232/kset.24.4.193.

[18] W. R. Sherman and A. B.pu Craig, Understanding Virtual Reality: Interface, Application, and Design. San Francisco: Morgan Kaufmann Publisher, 2003.

[19] Á. Di Serio, M. B. Ibáñez, and C. D. Kloos, "Impact of an augmented reality system on students' motivation for a visual art course," Computers and Education, vol. 68, pp. 586-596, 2013, doi: 10.1016/j.compedu.2012.03.002.

[20] R. T. Azuma, "A survey of augmented reality," presence: teleoperators and virtual environments, vol. 6, no. 4, pp. 355-385, 1997, doi: 10.1162/pres.1997.6.4.355.

[21] C. Okoli, "A guide to conducting a standalone systematic literature review," Communications of the Association for Information Systems, vol. 37, no. 1, pp. 879-910, 2015, doi: 10.17705/1cais.03743
[22] S. S. Sundar et al., "Toward a theory of interactive media effects (TIME): Four models for explaining how interface features affect user psychology".in The Handbook of the Psychology of Communication Technology. John Wiley \& Sons, Inc, 2015, pp.4786

[23] T. W. Chen and S. S. Sundar, "“This app would like to use your current location to better serve you': Importance of user assent and system transparency in personalized mobile services," Conference on Human Factors in Computing Systems Proceedings, vol. 2018-April, pp. 1-13, 2018, doi: 10.1145/3173574.3174111.

[24] A. Syawaludin, Gunarhadi, and P. Rintayati, "Enhancing elementary school students' abstract reasoning in science learning through augmented reality-based interactive multimedia," Jurnal Pendidikan IPA Indonesia, vol. 8, no. 2, pp. 288 297, 2019, doi: 10.15294/jpii.v8i2.19249.

[25] A. Syawaludin, Gunarhadi, and P. Rintayati, "Development of augmented reality-based interactive multimedia to improve critical thinking skills in science learning," International Journal of Instruction, vol. 12, no. 4, pp. 331-344, 2019, doi: 10.29333/iji.2019.12421a.

[26] R. Rozalinda, Y. Rozimela, and D. Anwar, "The ability of english department students in writing cause and effect essay in Universitas Negeri Padang," in Icoelt 2019, March 2020, vol. 411. pp. 402-407, doi: 10.2991/assehr.k.200306.067.

[27] M. L. R. Jannah, F. S. Irwansyah, and N. Widayani, "Making interactive learning media based on augmented reality on the concept of molecular chirality," Journal of Physics: Conference Series, vol. 1155, no. 1, 2019, doi: 10.1088/17426596/1155/1/012009.

[28] S. Radosavljevic, V. Radosavljevic, and B. Grgurovic, "The potential of implementing augmented reality into vocational higher education through mobile learning," Interactive Learning Environments, vol. 28, no. 4, pp. 404-418, 2020, doi: 10.1080/10494820.2018.1528286.

[29] F. Torres, L. A. N. Tovar, and M. C. Egremy, "Virtual interactive laboratory applied to high schools programs," Procedia Computer Science, vol. 75, no. Vare, pp. 233-238, 2015, doi: 10.1016/j.procs.2015.12.243.

[30] H. Ardiny and E. Khanmirza, "The role of ar and vr technologies in education developments: opportunities and challenges," Proceedings of the 6th RSI International Conference on Robotics and Mechatronics, IcRoM 2018, no. IcRoM, pp. 482487, 2019, doi: 10.1109/ICRoM.2018.8657615.

[31] W. D. Sasongko and I. Widiastuti, "Virtual lab for 
vocational education in Indonesia: A review of the literature," in AIP Conference Proceedings, 2019, vol. 2194, doi: 10.1063/1.5139845.

[32] M. S. Murfi and K. Rukun, "Pengembangan rancangan media pembelajaran augmented reality perangkat jaringan komputer," INVOTEK: Jurnal Inovasi Vokasional dan Teknologi, vol. 20, no. 1, pp. 69-76, 2020, doi: 10.24036/invotek.v20i1.702.

[33] T. Prasetiyo, P. Setyosari, and S. Sihkabuden, "Pengembangan Media augmented reality untuk program keahlian teknik gambar bangunan di sekolah menengah kejuruan," JINOTEP (Jurnal Inovasi dan Teknologi Pembelajaran) Kajian dan Riset dalam Teknologi Pembelajaran, vol. 4, no. 1, pp. 37-46, 2018, doi: 10.17977/um031v4i12017p037.

[34] N. Kurniawan, "Pengembangan augmented reality sebagai media pembelajaran pengenalan komponen pneumatik di SMK," Jurnal Pendidikan Teknologi dan Kejuruan, vol. 14, no. 2, pp. 136-144, 2017, doi: 10.23887/jptk-undiksha.v14i2.10443.

[35] A. Najib and N. Yuniarti, "Pengembangan media pembelajaran board game berbasis augmented reality pada mata pelajaran the development of learning media on augmented reality board," Jurnal Pendidikan Teknik Mekatronika, vol. 8, no. 1, pp. 9-19, 2018.

[36] A. Suryanto, D. A. Kusumawati, and I. M. H. Sanhoury, "Development of augmented reality technology based learning media of lathe machines," Jurnal Pendidikan Teknologi dan Kejuruan, vol. 24, no. 1, pp. 32-38, 2018, doi: 10.21831/jptk.v24i1.18245.

[37] M. Firdaus, Mastuki, and J. F. Allan, "The AlKesFar app, a mobile augmented reality on learning media tools for Indonesian pharmacy school," Proceedings of the 3rd International Conference on Informatics and Computing, ICIC 2018, pp. 1-5, 2018, doi: 10.1109/IAC.2018.8780491.

[38] A. Suryadi et al., "Education-based augmented reality applications for heat learning media content lesson in physics," Journal of Physics: Conference Series, vol. 1280, no. 3, pp. 0-4, 2019, doi: 10.1088/1742-6596/1280/3/032042.

[39] T. Yuliono and P. Rintayati, "The promising roles of augmented reality in educational setting: a review of the literature," International Journal of Educational Methodology, vol. 4, no. 3, pp. 125132, 2018, doi: 10.12973/ijem.4.3.125.

[40] M. Sirakaya and E. K. Cakmak, "Effects of augmented reality on student achievement and selfefficacy in vocational education and training," International Journal for Research in Vocational
Education and Training, vol. 5, no. 1, pp. 1-18, 2018, doi: 10.13152/IJRVET.5.1.1.

[41] M. Bower et al., "Augmented Reality in education - cases, places and potentials," Educational Media International, vol. 51, no. 1, pp. 1-15, 2014, doi 10.1080/09523987.2014.889400.

[42] P. Diegmann et al., "Benefits of augmented reality in educational environments - a systematic literature review," Wirtschaftsinformatik Proceedings, $\mathrm{p}$ 103, 2015, [Online]. Available: http://aisel.aisnet.org/wi2015/103.

[43] K. K. Bhagat et al., "To use augmented reality or not in formative assessment: a comparative study," Interactive Learning Environments, vol. 27, no. 56, pp. 830-840, 2019, doi: 10.1080/10494820.2018.1489857.

[44] M. Sirakaya and D. Alsancak S, "Trends in Educational Augmented Reality Studies: A Systematic Review," Malaysian Online Journal of Educational Technology, vol. 6, no. 2, pp. 60-74, 2018, doi: 10.17220/mojet.2018.02.005.

[45] N. A. M. El Sayed and H. H. Zayed, "ARSC: Augmented Reality Student Card An Augmented Reality Soultion for the Education field," Computers and Education, vol. 56, no. 4, pp. 113120, 2011. 